Canadian Art Review

\title{
The Shrine of St. Gertrude of Nivelles and the Process of Gothic Design
}

\author{
James Bugslag
}

Volume 20, numéro 1-2, 1993

URI : https://id.erudit.org/iderudit/1072747ar

DOI : https://doi.org/10.7202/1072747ar

Aller au sommaire du numéro

\section{Éditeur(s)}

UAAC-AAUC (University Art Association of Canada | Association d'art des universités du Canada)

\section{ISSN}

0315-9906 (imprimé)

1918-4778 (numérique)

Découvrir la revue

Citer cet article

Bugslag, J. (1993). The Shrine of St. Gertrude of Nivelles and the Process of Gothic Design. RACAR : Revue d'art canadienne / Canadian Art Review, 20(1-2), 16-28. https://doi.org/10.7202/1072747ar

\section{Résumé de l'article}

La châsse de Sainte-Gertrude de Nivelles reste en orfèvrerie un exemple précoce de "micro-architecture." Le contrat qui existe toujours remonte à 1272 et montre clairement que le projet et l'exécution étaient deux opérations complètement séparées. Cela laisse aussi entendre qu'un dessin du projet accompagnait le contrat. À mon avis, le dessin représentait une élévation architecturale très minutieusement tracée et les nombreuses références architecturales de la châsse renvoyaient à des édifices plus anciens d'Ile-de-France et, sans aucun doute, les dessins d'architecture constituaient les moyens par lesquels ils étaient fixés dans le projet. En fait, on retrouve d'autres exemples de dessins d'architecture accompagnant les contrats à cette époque, période pendant laquelle la séparation entre le concept et l'exécution s'affirmait de plus en plus dans un grand nombre de traditions artisanales. La conception du projet qui peut être perçue dans la châsse de Sainte-Gertrude offrait beaucoup de similitude avec les écrits de saint Thomas d'Aquin qui assimilent la pureté formelle et la réalisation précise d'un concept. Le fondement géométrique du dessin d'architecture le rangeait du côté de la forme intelligible, ce qui permettait de croire également dans les qualités transcendantes du dessein. Cette nouvelle méthode de transfert de la forme devenait possible grâce aux nouvelles techniques de dessin, y compris l'élévation architecturale, et favorisait l'éclosion de la "micro-architecture." Cette méthode indique aussi un développement substantiel dans le processus de la conceptualisation "gothique" qui eut des effets sur la formation artisanale, les pratiques d'atelier, le statut des objets d'art et dans la position sociale du concepteur.
Tous droits réservés (C) UAAC-AAUC (University Art Association of Canada | Association d'art des universités du Canada), 1994
Ce document est protégé par la loi sur le droit d'auteur. L'utilisation des services d'Érudit (y compris la reproduction) est assujettie à sa politique d'utilisation que vous pouvez consulter en ligne.

https://apropos.erudit.org/fr/usagers/politique-dutilisation/ 


\title{
The Shrine of St. Gertrude of Nivelles and the Process of Gothic Design*
}

\author{
James BugsLaG, McGill University
}

\section{Résumé}

$\square$

a châsse de Sainte-Gertrude de Nivelles reste en orfèvrerie un exemple précoce de "micro-architecture." Le contrat qui existe toujours remonte à 1272 et montre clairement que le projet et l'exécution étaient deux opérations complètement séparées. Cela laisse aussi entendre qu'un dessin du projet accompagnait le contrat. A mon avis, le dessin représentait une élévation architecturale très minutieusement tracée et les nombreuses références architecturales de la châsse renvoyaient à des édifices plus anciens d'lle-de-France et, sans aucun doute, les dessins d'architecture constituaient les moyens par lesquels ils étaient fixés dans le projet. En fait, on retrouve d'autres exemples de dessins d'architecture accompagnant les contrats à cette époque, période pendant laquelle la séparation entre le concept et l'exécution s'affirmait de plus en plus dans un grand nombre de tradi- tions artisanales. La conception du projet qui peut être perçue dans la châsse de Sainte-Gertrude offrait beaucoup de similitude avec les écrits de saint Thomas d'Aquin qui assimilent la pureté formelle et la réalisation précise d'un concept. Le fondement géométrique du dessin d'architecture le rangeait du côté de la forme intelligible, ce qui permettait de croire également dans les qualités transcendantes du dessein. Cette nouvelle méthode de transfert de la forme devenait possible grâce aux nouvelles techniques de dessin, y compris l'élévation architecturale, et favorisait l'éclosion de la "micro-architecture." Cette méthode indique aussi un développement substantiel dans le processus de la conceptualisation "gothique" qui eut des effets sur la formation artisanale, les pratiques d'atelier, le statut des objets d'art et dans la position sociale du concepteur.
$\mathrm{R}$ eliquary shrines constituted some of the largest and most spectacular accomplishments of medieval goldsmiths. Disappointingly few have survived, but amongst those which have there is important evidence for reconstructing the process of Gothic design. Around the middle of the 13th century there was a dramatic change in the appearance of reliquary shrines in northern Europe. For some time shrines, such as the Three Kings Reliquary in Cologne, ca.1182-1230, had taken a generalized architectural form, ${ }^{1}$ but at this time what had once been generalized became very specific. These new shrines fall within François Bucher's category of "micro-architecture." 2 The older style of shrine soon began to fall out of production, and the new style set a demanding standard, which not only encompassed shrines but many aspects of metalwork production. There is evidence that Paris thrived as a centre of production in this new environment. ${ }^{3}$

It is the contention of this essay that this change cannot be considered in purely formal terms. The reasons for such a dramatic shift involved new design techniques of considerable sophistication, prominent amongst them being architectural drafting. An early application of these design techniques can be seen in the Shrine of St. Gertrude of Nivelles. Uniquely for a major, extant piece of 13 th-century metalwork, the contract for the shrine survives intact. In fact, the contract is now more complete than the shrine itself, which suffered grievous damage during the Second World War, and only fragments of it now survive. ${ }^{4}$ Pre-war photographs (Fig. 1), together with a detailed plaster cast in Nivelles (Fig. 2), supplement our knowledge of the shrine. An analysis of the architectural elements of the
Shrine of St. Gertrude, in relation to an analysis of the contract, provides enlightening evidence of the process of Gothic design, which, since so little documentary evidence from this period survives for design in such central fields as architecture, has relevance far beyond the confines of one single craft tradition. An analogical comparison of this design process with contemporary theoretical writings concerning art suggests some of the new artistic directions which were being explored in the later 13th century.

The contract for the Shrine of St. Gertrude survives in the form of a copy included in a cartulary, compiled in the late 15 th and early 16th centuries, now in the Archives générales du royaume in Brussels. ${ }^{5}$ It is dated 18 September 1272, an early date for the survival of any contract of an artistic nature and is written in French, rather than Latin which, for instance, was used for the surviving contract of 1292 for the Shrine of St. John at Beverley Minster. ${ }^{6}$ One of the most remarkable aspects of the contract is that it makes clear that the design and execution of the shrine were completely separate. The contract is between the chapter of the collegiate house of nuns at Nivelles, on the one hand, and two goldsmiths, Nicolas de Douai and Jaquemon de Nivelles, on the other. The contract specified that the new shrine was to be as long or longer than the old shrine and of an appropriate width and height, with four gables, according to the drawing - the "pourtraiture" - which accompanied the contract. This drawing was made by another goldsmith, Master Jakenez or Jakemon d'Anchin, who is later referred to as a monk of Anchin. He must thus be considered the designer of the shrine, and the two contracting goldsmiths the craftsmen who executed it. The draw- 
Figure I. Shrine of St. Gertrude of Nivelles, gable end (Phot: Copyright A.C.L. - Bruxelles).

ing, unfortunately, does not survive, but there is evidence both in the form of the shrine itself and in the text of the contract which suggests that it was an architectural elevation. ${ }^{7}$

Before this is considered, however, it must be stated that the relation between the initial design for the shrine as specified in the contract and the shrine as built is certainly not straightforward. For one thing, the contract states that the design is open to improvement and amendment-" par emmiadremenche et par l'amendement"-probably either by the designer or the executing goldsmiths. This is all the more relevant a consideration since the shrine took a considerable length of time to complete - as much as twenty-six years; the translation of the relics into the new shrine probably only took place on 31 May $1298 .^{8}$ This was a long enough period that the chapter could have added new specifications, and in fact some aspects of the shrine suggest that this was the case. The "aisle" roofs, for instance, are decorated with embossed diapering containing heraldic devices: the fleursde-lys and castles of the Capetian royal house and the lions of Brabant. This combination in all probability refers specifically to the Queen of France, Marie de Brabant, who was only married to King Philip III in August 1274, two years after the contract for the shrine was dated. ${ }^{9}$ It is possible that the patronage implied by her arms on the shrine predates her marriage, but even if that were the case the arms as they appear on the shrine must

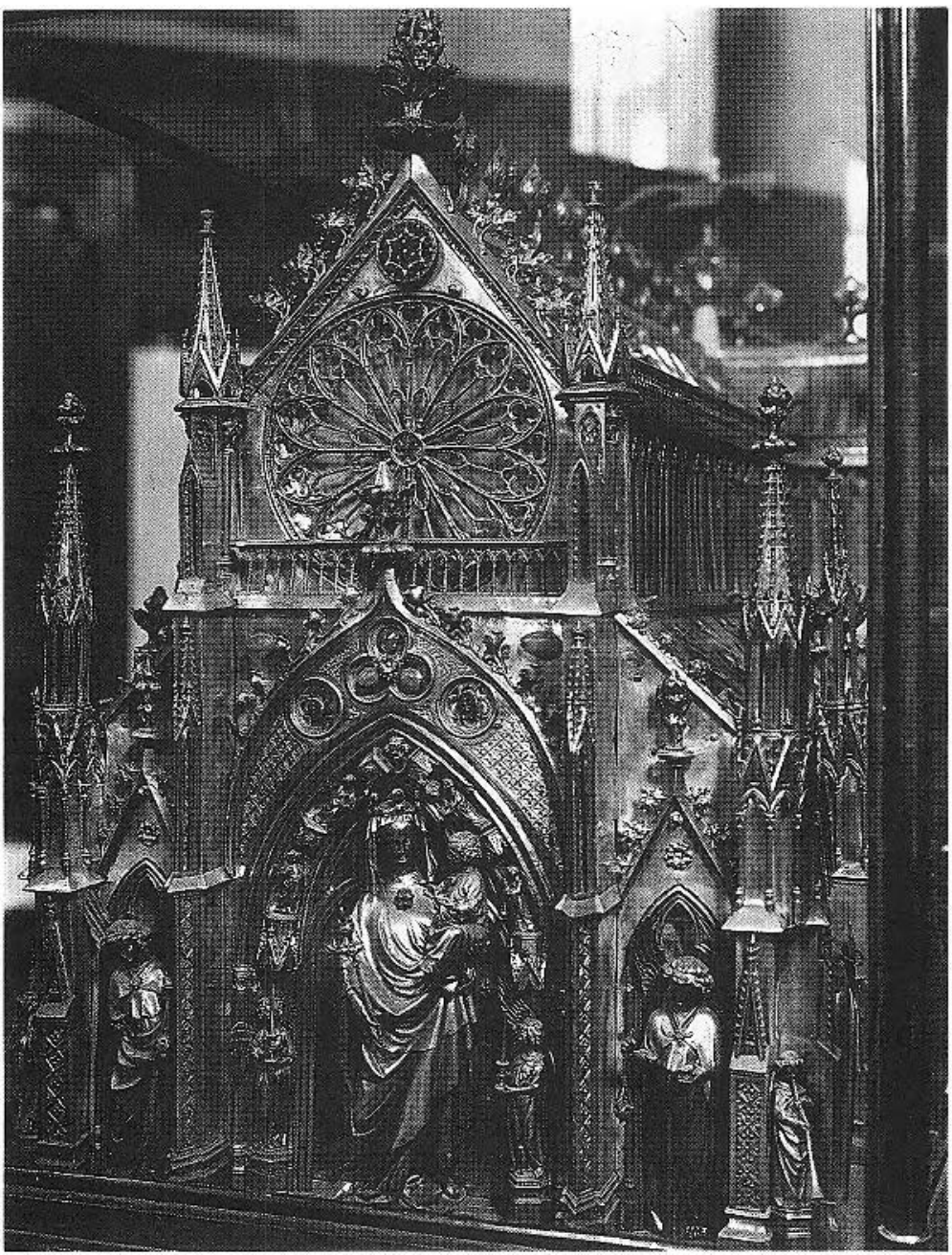
represent a change from the original conception of the shrine. The materials of the shrine also appear to be different from the gold and silver specified in the contract, consisting largely of an alloy of silver and copper. ${ }^{10}$ Similarly, there is no reference in the contract to the precious stones, pearls or de plique enamels which decorate the shrine, the availability of which could have determined aspects of its final appearance. ${ }^{11}$ It might also be observed that stylistic differences have been noted between the figural images on the shrine. ${ }^{12}$ The basic massing and shape, however, must have been determined from the outset by the wooden structure onto which the metalwork was to fit; this was provided by the chapter to the executing goldsmiths and was perhaps produced under the direction of the designer: "li capitle livreat as devant dit Nicholon et Jaquemon ... le fust tailliet tot sus à le duise de maistre pour mettre us l'orfaverie."13 There are, furthermore, substantial aspects of the shrine's final appearance which suggest very specific models and the application of drafting techniques. These and the possibilities

of what information the contract drawing could reasonably be expected to contain will form the focus of this study.

Drawing, it would appear, had long been established amongst goldsmiths as an aid to design. In the late 12th century, Alexander Neckham described a goldsmith's workshop, probably based on his personal observations of goldsmiths in Paris, where he taught at the school of the Petit-pont from ca. $1180 .{ }^{14}$ His description testifies to the use of working drawings by goldsmiths. He wrote that the goldsmith "must also be as skilled in the work of the quill as in the work of carving and as in the work of casting and as in the work of chasing. And let his untaught apprentice have a waxed table, or one anointed with whiting or rubbed over with clay, so that he may portray and draw little flowers thereon in various manners." 15 This does not tell us very much about the way such drawings were used, ${ }^{16}$ and according to Marian Campbell: "The sketches or working drawings of goldsmiths are great rarities, even from the Renaissance; there is virtually no extant direct evidence from 
Figure 2. Plaster cast of the Shrine of St. Gertrude of Nivelles, long side (Phor: Copyright A.C.L. - Bruxelles).

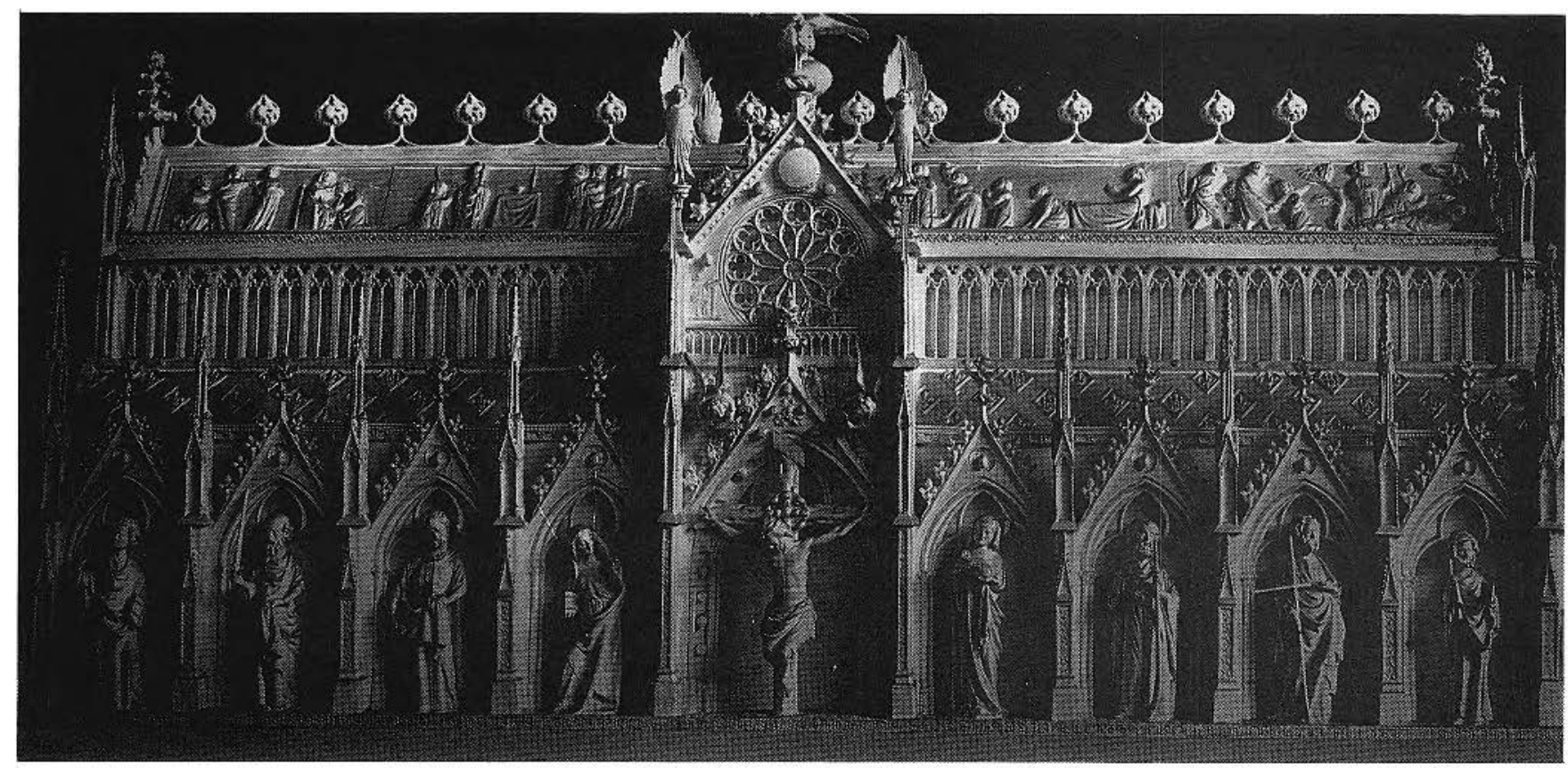

the Middle Ages ... to show how goldsmiths arrived at a design."17

The lost Nivelles drawing may, however, provide indirect evidence of that process. Nevertheless, it was certainly not a working drawing, as it presented a fully worked-out design (or at least almost fully worked-out, since the contract specifies that the design is open to improvement and amendment). The fact that the drawing was presented as an integral accompaniment to a contract would suggest that, whatever change to which it was subject, it must have included enough finished detail to serve as a legally binding model. From the text of the contract and from the form of the shrine, it seems extremely likely that the drawing took the form of a measured architectural elevation, of a kind which had only recently been developed in the masons' lodges of northern France and the Rhine Valley. The Reims palimpsest drawings, which probably date from the 1240 s, constitute some of the earliest evidence for such drawings. ${ }^{18}$ Amongst these, Robert Branner has identified designs not just for architecture but almost certainly for wooden choir stalls and, more speculatively, for perhaps a metalwork chalice. Elevation drawings certainly connected with metalwork survive from a later date, although few of these have yet been published. ${ }^{19}$

The Nivelles contract drawing was very probably such an elevation drawing, undoubtedly of a highly architectural nature, comparable to the elevations for architectural facades that survive from the 1250 s onwards, such as Drawings $A$ and $A^{1}$ in Strasbourg (Fig. 3), showing early designs for the west facade of the cathedral there. ${ }^{20}$ The exactitude of trac- ery patterns and buttress forms which can be seen in these drawings is very similar to that of the architectural details of the shrine. The architectural details of the shrine, moreover, are closely comparable to built architecture of the preceding generation. Some obvious connections have already been made between elements of various buildings and the shrine, ${ }^{21}$ but more can be said about this. First, however, there is indirect evidence in the contract itself for reconstructing the contract drawing as an architectural elevation. Provision is made in the text of the contract for the makers of the shrine to submit a test piece to the chapter by the following Lent, and the nature of the test piece is concisely specified. It is to consist of a middle gable, "un pignon moien," another architectural feature called "un petit deleis," probably one of the flanking niches, and the piers belonging to it, "et les pilers qui y afieront," but without the images, "sans lez imagenez." Claussen has offered an explanation for these specifications to which I cannot subscribe. ${ }^{22} \mathrm{He}$ maintains that the two contracted masters would themselves have execured the statues for the shrine, leaving the architectural bits to assistants and apprentices, and it was only the latter that the chapter were unsure of. This explanation goes against almost everything we know of medieval workshop practice. There is no question that the two master goldsmiths who signed the Nivelles contract (or, for that matter, any who may have replaced them) would have assumed full responsibility for the work of any assistants and apprentices they had working for them.

Moreover, the complex and precise nature of the architectural elements of the shrine are not such as could be en- 
Figure 3. Facade Drawing A', Musée de l'Oeurre-Notre-Dame, Strasbourg, Inv. no. 2 (Photo: courtesy of Musees de la Ville de Strasbourg).

trusted to apprentices. In fact, there is some contemporary evidence of specialization amongst established goldsmiths along architectural lines. This is contained in the copious documentation of the Shrine of St. Edward the Confessor, commissioned by King Henry III for Westminster Abbey aus early as 1241. Like the Nivelles shrine, the Shrine of St. Edward took an enormously long time to complete. It was still not finished at Henry's death in 1272; the recorded donations of single figures, as well as the occasional pawning of figures already prepared for the shrine, make clear that the enormous expense of the metals and precious stones for such a project put it almost onto the financial scale of a church-building project. A list of itemized expenditures on the shrine was drawn up at Henry's death, and wages are recorded for four goldsmiths. Two of these goldsmiths did the lion's share of the work: Edward of Westminster, the keeper of the shrine, was paid 73 shillings and Walter 4 lb, 11 sh., $4 \mathrm{~d}$. The other two goldsmiths, Robert and Thomas, received much less, 6 marks and 4 shillings, respectively, but it is recorded that this was specifically for work on bases and columns for the shrine. ${ }^{23}$ The shrine itself was destroyed in 1555, but a contemporary manuscript illumination depicting it clearly shows such architectural features. ${ }^{24}$ It is equally clear, however, that the degree of architecturalization in the Shrine of St. Edward, even making allowance for any unreliability of the illumination, was much less than that of the Shrine of St.

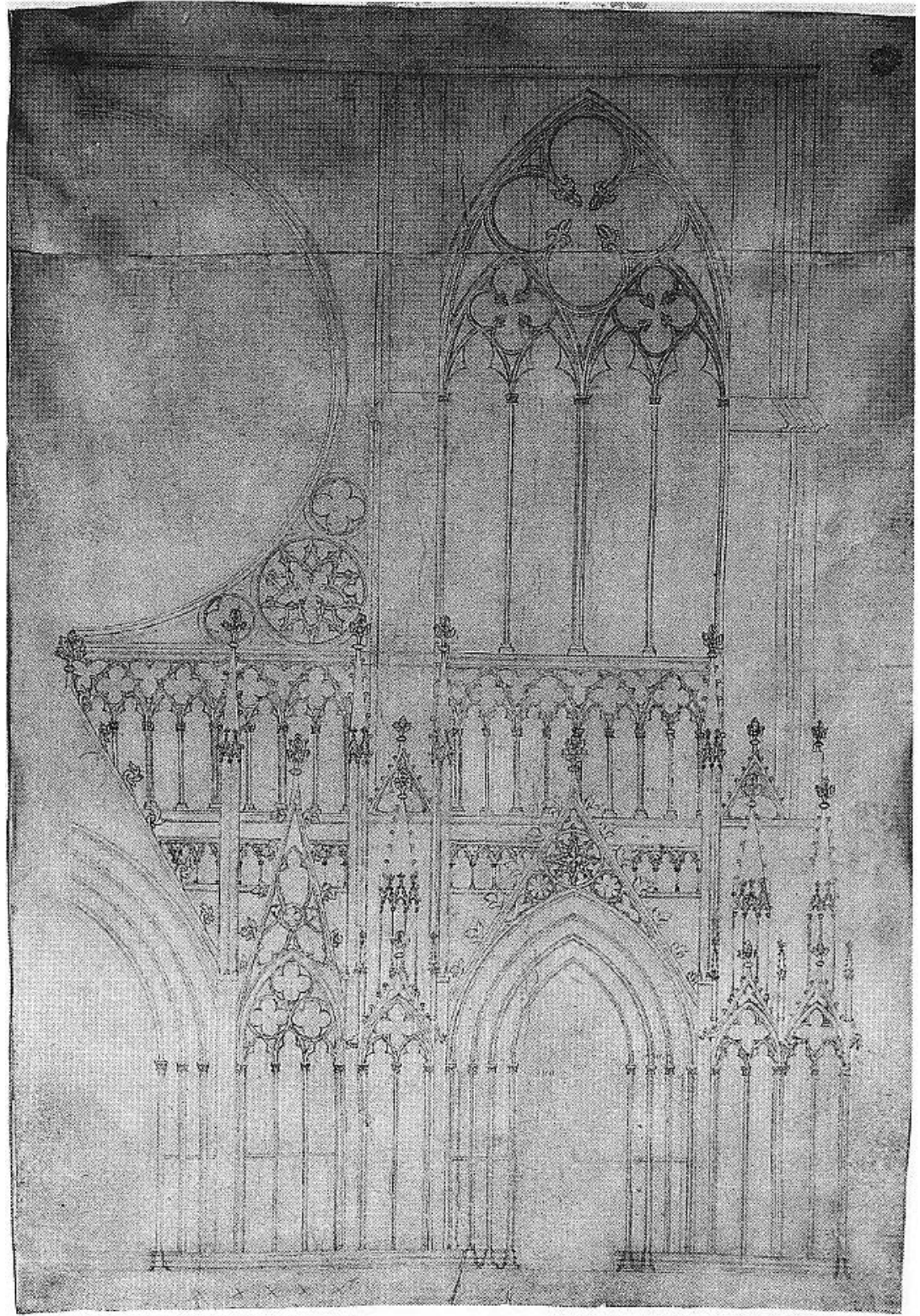
Gertrude, which would have required substantially more specialization in this respect.

My own interpretation of the terms of the test piece is that what was in question was not the general competence of the goldsmiths under contract, which would certainly include their ability to do figural work and with which the chapter of Nivelles in all likelihood was familiar, but rather their ability to use and copy drafted architectural drawings. The precision of the architectural detailing on the shrine could only have been accomplished by means of a detailed knowledge of architecture, which at this time could not be generally expected of a goldsmith. Specific architectural details could easily have been transmitted by means of drafted elevation drawings, however, and an examination

of the architectural aspects of the shrine makes such an interpretation appealing. ${ }^{25}$

The close architectural references in the Shrine of St. Gertrude are obvious even to a casual observer. Two things are worth noting about them. Firstly, embedded in the design are elements which bear extremely close resemblance to details of built architecture - and built architecture of a particular kind. The architectural references overwhelmingly concentrate on buildings from the Ile-de-France from the previous generation, all of them instrumental in the development of Rayonnant architecture. This is all the more surprising since the shrine was made in Nivelles, in southern 
Figure 4. Paris, Notre-Dame, north transept (Photo: Michael Malloy/Geoffrey Finch).

Belgium, by one goldsmith from Nivelles, and another, Nicolas de Douai, who could have practised either in Douai or Arras, ${ }^{26}$ and it was designed by a monk from Anchin, which is very close to Douai. Secondly, however, the very precise architectural references in the shrine are cited in a slightly differentand occasionally even unarchitectonic-context from their large-scale referends, and they are also combined with less precise and even non-architectural details.

The design of the rose windows decorating the two gable ends (Fig. 1) has invited the most comparison thus far. It has been compared with both the west rose of Reims Cathedral, probably designed in the mid-1250s, and the north transept rose of Notre-Dame in Paris, probably also built during the 1250 s (Fig. 4). ${ }^{27}$ There are slight differences in both comparisons. In the Reims west rose, the radiating lobes end in quatrefoils, rather than trefoils, as on the shrine, but like the shrine the Reims west rose has twelve divisions. The Notre-Dame north rose, on the other hand, has sixteen divisions, but the individual lobes feature trefoils, like those on the shrine. Despite these differences, it should be stressed that these are not approximate comparisons, but remarkably precise ones. There can be no doube that the shrine copies the design of such roses, right down to the use of capitals on the main radiating ribs, just at the springings of the lobes. The Notre-Dame north transept also has a small, openwork, arcaded parapet at the base of the rose, a feature of all the roses used on the shrine. It has been noted, however, that the rose-in-square motif at the bottom of the Notre-Dame rose has not been copied in the shrine. ${ }^{28}$ That is certainly true. In fact, the arrangement on the shrine appears rather as if the design of the main rose at NotreDame were moved up into the gable at the top of the transept facade. That can be seen more clearly by looking at the later south transept facade of Notre-Dame (Fig. 6), begun in 1259 and probably finished by $1267,{ }^{29}$ where the decorative relief roundels surrounding the upper rose are reflected on the shrine by translucent enamel medallions. On both transept facades at Notre-Dame, this upper gable is flanked by polygonal buttresses with short spires, as on the shrine. ${ }^{30}$ The transept facades of Notre-Dame also provide a precedent for the prominent oblique setting of buttress elements found on the shrine, and even for the incised diapering on those obliquely sec elements (Figs. 1, 5). By the early 1270s, obliquely turned supports of this kind were still rather upto-date and telling architectural features. ${ }^{31}$

The substantial polygonal turrets flanking the end facades (Fig. 1) are reminiscent of those on the Lady Chapel at Saint-Germer-de-Fly, which dates from the 1250s and also constitutes a direct reflection of both Ile-de-France and French royal taste. ${ }^{32}$ These turrets also feature two tiers of gabled arcades topped by a polygonal spire, and it should perhaps be noted that the rose design at Saint-Germer, while more exactly comparable to the Reims west rose, is certainly of the same family as the design used for the end roses of the shrine. The structural rationale for these massive turrets, however, is lost in the shrine, where they flank low aisles rather than the tall, single vessel of the vaulted SaintGermer Lady Chapel.

The roses in the gables on the sides of the shrine are much smaller than the end roses, and there is comparably 
Figure 5. Paris, Notre-Dame, north transept, pinnacle flanking central gable (Photo: author).

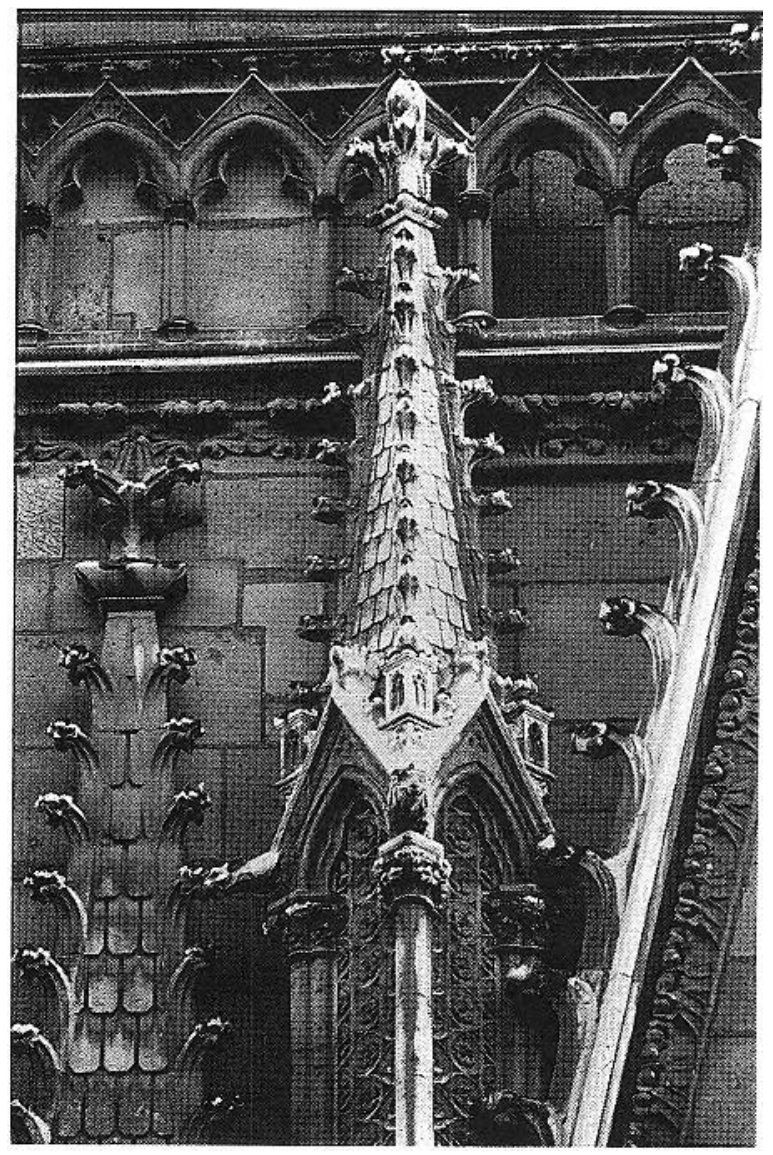

less scope for detail in them (Fig. 2). They are thus of a simpler design, although this design would still have required substantial geometrical precision in its layout and execution. Moreover, this rose design belongs to a different family than that on the gable ends of the shrine. It features a row of oculi around the perimeter, each aligning with a radiating rib which is joined to its neighbours by trefoil arches between the oculi. This family of rose designs is exemplified by the north transept rose of the Abbey Church of Saint-Denis, ${ }^{33}$ which has twelve units in the centre, like the shrine rose, but then subdivides into twenty-four parts (Fig. 7). It is certainly possible that the rose design on the shrine represents a cut-down version of the Saint-Denis type of design.

The "clerestory" arcade which decorates the upper side walls of the shrine (Fig. 2) is also extremely similar to the clairevoies below such roses as those of the Notre-Dame and Saint-Denis north transepts (Figs. 4, 7). However, in both of these examples the comparison is not exact, because the tracery element above each pair of lights on the shrine is a quatrefoil, differing slightly from the two architectural examples. At Saint-Denis this tracery element is a trefoil, and in the Notre-Dame north transept, although quatre-
Figure 6. Paris, Notre-Dame, south transept (Photo: Michael Malloy/Geoffrey Finch).

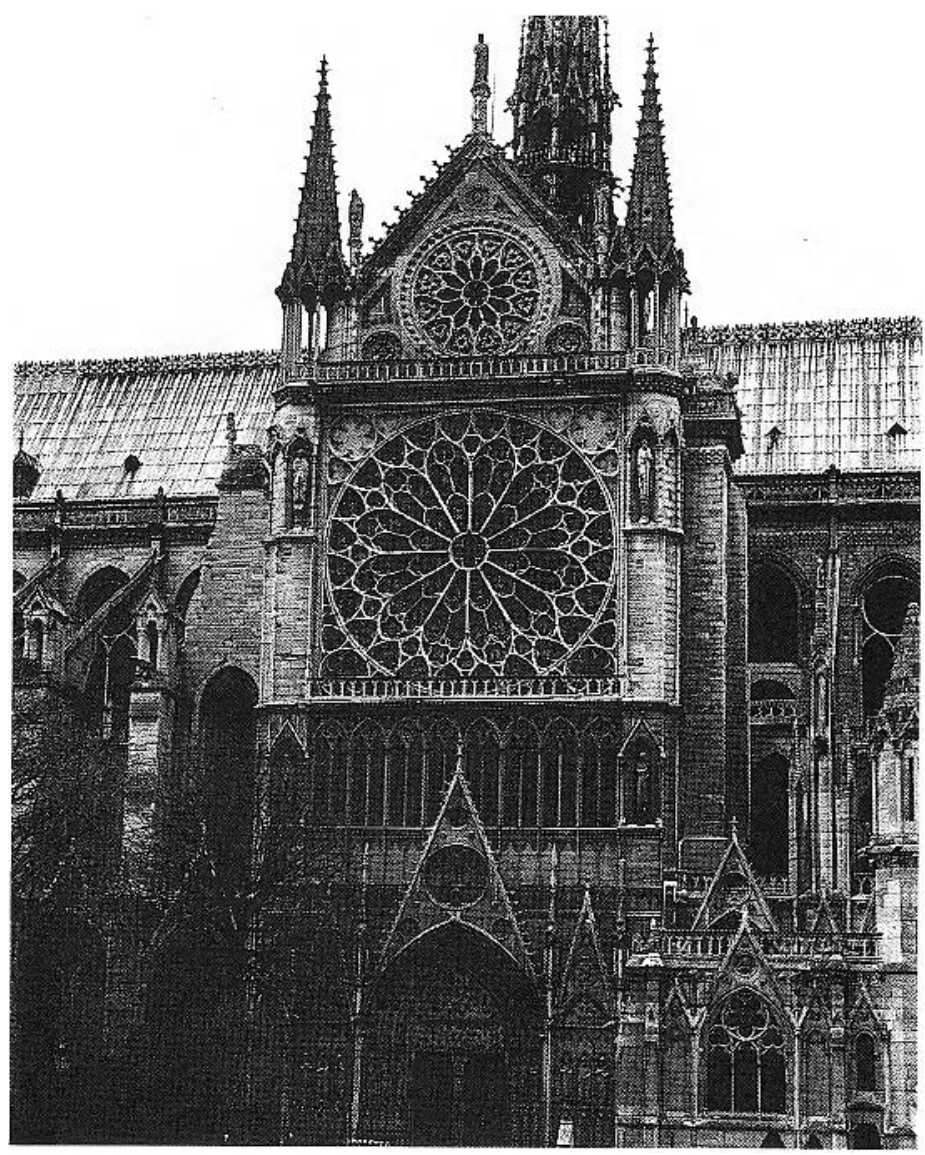

foils are used, they are set with a cusp up, rather than a lobe, as on the shrine, and the trefoils in the spandrels between doublets are, again, set differently than on the shrine. But it cannot be doubted that a comparable clairevoie was the model for that of the shrine. This is highly indicative, in relation to the design of the shrine as a whole, because while the feature has some quite precise architectural models, it is not being used on the shrine below a rose window but, in a highly unarchitectonic way, as a clerestory. ${ }^{34}$ So, once again, this is a precise architectural reference being used considerably out of context.

Virtually all of the above-mentioned architectural details of the shrine could have been suggested by a couple of elevation drawings of church transepts. Both the accuracy of architectural detailing on the shrine and the freedom with which that detailing is used out of context, very nicely fit the model I am proposing of a goldsmith making use of architectural drafting for the purpose of design. As it happens, the only exact comparison I have found for the clairvoie design on the shrine is on Drawings $A$ and $A^{1}$ in Strasbourg (Fig. 3), which represent early, unbuilt designs, dating from the 1250 s or 1260 s, for the west facade of Strasbourg Cathedral. 
Figure 7. Saint-Denis, north transept (Photo: from Jean Bony, French Gothic Architecture of the 12th and 13th Centuries, courtesy of the Regents of the University of California).

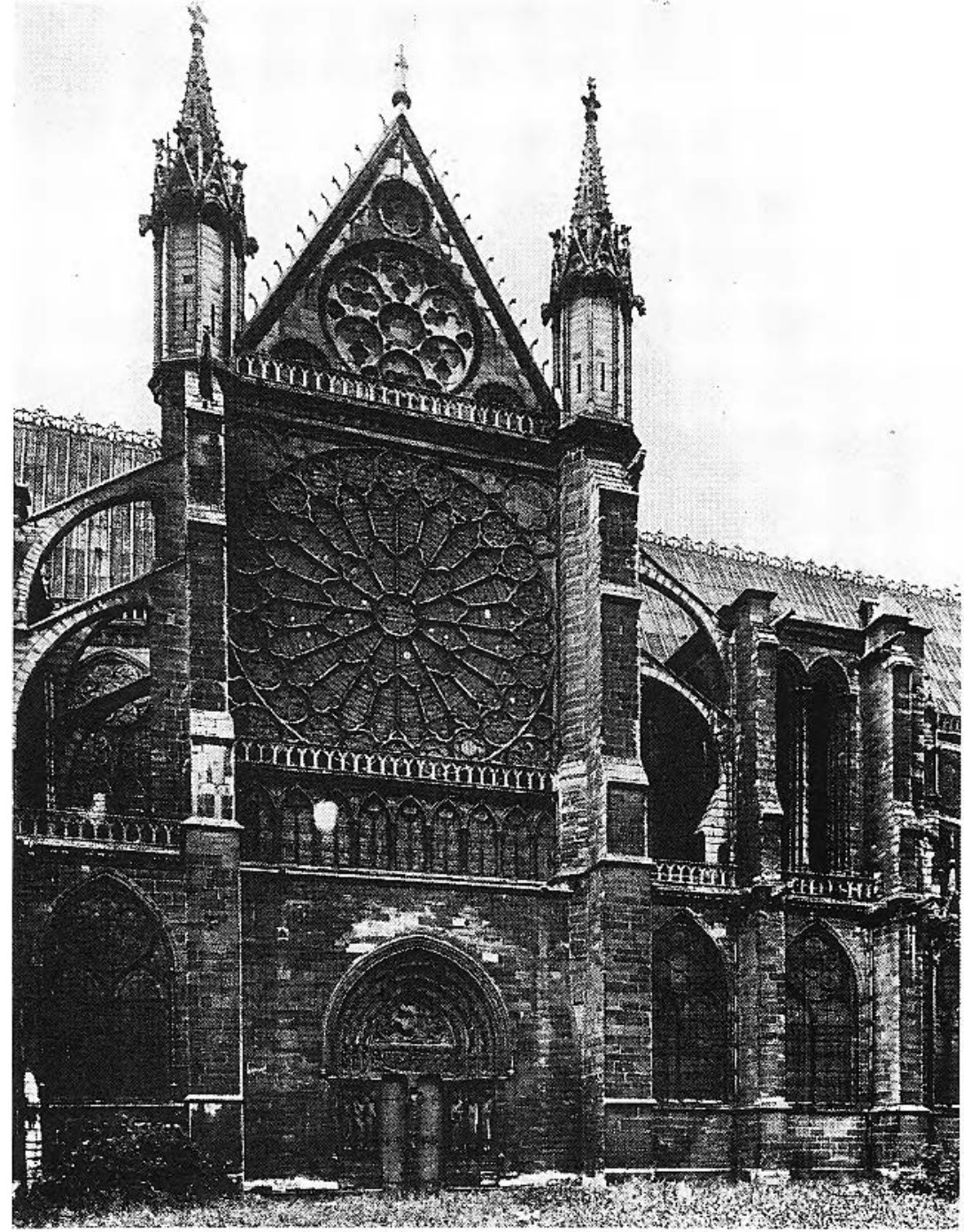

in French and, in fact, all continental art of the period. Ogees only became prominent in England during the 1290s, with the development of the Decorated style of architecture. Occasional examples can, however, be found on the continent from the mid-13th century. ${ }^{37}$ It might also be pointed out that, in combination with the "portal sculpture" below, this feature is remarkably out of scale in relation to much of the other, more upto-date architectural imagery.

The double portal arches apart, almost all of the architectural comparisons which can be made with the shrine can be seen as participating in a dissemination of architectural ideas from the Ile-de-France during the third quarter of the 13 th century. ${ }^{38}$ In fact, the idea of highly architecturalized shrines appears to have emanated from Paris, as well. The earliest such shrine may well have been that made for the Sainte-Chapelle, which was probably completed by 1248 , unfortunately known only from drawings. ${ }^{39}$ The mid-13thcentury Shrine of St. Taurin of Évreux is perhaps the earliest surviving example of such a shrine, and the Floreffe Triptych, made shortly after 1254 , is another early metalwork example of "micro-architecture." 40 It would thus appear that metalwork played a significant role in the dissemination of architectural elements into other media.

It might even be said that, increasingly from this time, fully articulated "Gothic" began to be regarded as a generally ecclesi-

Perhaps the most prominent element of the shrine which does not fit this profile of architectural references is the arch/ ogee-gable form over each of the central figures on the gable ends of the shrine (Fig. 1). This consists of a pointed arch below, enclosing an abbreviated arrangement of portal sculpture, and a crocketed ogee arch above. The diapered field between them contains a large trilobe and two oculi, but in a loose arrangement that does not correspond to architectural practice. ${ }^{35}$ Such "double arches" can be found in canopies in both small-scale portal sculpture and stained glass from a somewhat earlier period; for instance, some of the canopies in the stained glass in the transept clerestory of Chartres Cathedral, probably dating from the 1230 s. $^{36}$ This relatively old-fashioned and generally small-scale feature, however, is combined in the shrine with an ogee arch, an element which is rather harder to evaluate, due to its rarity astical style, equally applicable to the design of a grand church and to the design of its furnishings, from large-scale items such as screens, choir stalls and tombs to smaller-scale objects such as shrines and plate; even two-dimensional church arts, such as stained glass, became influenced by architectural design from the mid-13th century. ${ }^{41}$ It would certainly be more difficult to find examples of the specific architectural features considered above in contemporary secular buildings than it is in ecclesiastical metalwork or church carpentry. It seems remarkable that such stylistic homogeneity would be formulated in a period in which oblations to relics were noticeably in decline ${ }^{42}$ and the simpler parish or friar's church was increasingly competing with the great cathedral or abbey church as a popular devotional focus; but perhaps the style can be said to represent an ideological ideal, the construction of which became all the more 
exacting with its increasing distance from social and religious realities. However this might be, the application of a homogeneous vocabulary of forms to a variety of media depended significantly on the incorporation of architectural drafting technology into the design process of non-architectural craft traditions.

The Nivelles contract, I believe, gives us valuable evidence of the process by which this came about. The drawing which accompanied the shrine must almost certainly have been an architectural elevation (perhaps more than one). The early history of architectural drawings in general, both in their appearance and their use, is incompletely known, and architectural drawings have only recently begun to be studied systematically. ${ }^{43}$ These investigations have understandably concentrated on the place of architectural drawings within the masons' lodges where they originated. It is not at all clear, however, that goldsmiths would have used architectural drawings in the same way as masons. In the case of the Shrine of St. Gertrude, it would appear that such drawings were used as sources of models to be copied in all of their singular and geometrically exact details, rather than as part of a geometrically generative process of design such, for instance, as is described in the 15th-century architectural design booklets of Mathes Roriczer and Hanns Schmuttermayer. ${ }^{44}$ This is suggested by the unarchitectonic ways in which precise architectural references are incorporated into the design of the shrine. Nevertheless, in order accurately to lay out and execute any of the tracery elements of the shrine, some drafting knowledge, in the form of constructive or practical geometry, must have been necessary on the part of both designer and executing craftsmen. It remains to be seen just how practical geometry, as it was used in a variety of craft workshops, was aided by architectural drawings, but in the case of the Shrine of St. Gertrude they certainly appear to have facilitated the exact transmission of Ile-de-France architectural ideas, both geographically and into another medium.

The Nivelles contract provides us with an example of another specific use to which architectural drawings were sometimes put: namely, as a legally binding addendum to contracts. This function is perhaps best known through Franklin Toker's study of the 1340 contract for the Palazzo Sansedoni in Siena. ${ }^{45}$ The accompanying elevation is included on the same piece of parchment as the text of the Siena contract, although it should be noted that Toker believes this elevation to be a copy or tracing, rather than a precisely drafted elevation per se. By this time, there is other evidence for the practice, significantly from the Nivelles region. For instance, there is a contract for an incised tomb slab surviving in the Archives de l'état in Mons which also makes reference to an accompanying architectural drawing. The contract, dated 8 September 1311 at Tournai, specifies that the image of the deceased is to have a pier to each side defined in "vraie machonnerie," with bases and capitals, and with "cimais," as it appears on the executor's parchment, and that these two piers are to have a tabernacle, also to resemble sufficiently the one on the executor's parchment. ${ }^{46}$ The slab in question is lost, but undoubtedly it would have featured the precise architectural detailing which had become common on tomb slabs by that time. ${ }^{47}$ As with the Shrine of St. Gertrude, it appears likely that the drawing accompanying the contract was a precisely drafted architectural elevation. The later contract for the Shrine of St. Germain, for the Abbey of Saint-Germain-des-Prés in Paris, dated 18 February 1408 and surviving in the Archives nationales in Paris, also makes reference to a "pourtraiture et patron," and its highly architecturalized form, now known only through an engraving of 1724 , again makes architectural elevations likely. ${ }^{48}$

We appear to have, in all of these examples of drawings accompanying contracts, clear examples of the separation of design and execution, which can also be found in other documents of the time, such as the English royal accounts, which make clear that the coronation chair, which still survives in Westminster Abbey, was designed by Adam the Goldsmith, but was made by, or at least under the supervision of the king's painter, Walter of Durham, during the $1290 \mathrm{~s}^{49}$ And it will also be recalled that Jean Pucelle is documented as having designed a seal for the Confraternity of Saint-Jacques-aux-Pèlerins in Paris, 1319/24. ${ }^{50}$

Of all these examples of the separation of design and execution, the Shrine of St. Gertrude appears to be the earliest well-documented case. ${ }^{51}$ The importance of this evidence cannot be overestimated. The separation of design and execution is usually considered one of the significant developments of the Renaissance and is discussed in relation to the likes of Albrecht Dürer or Benvenuto Cellini. ${ }^{52}$ At least in a limited context, it appears that the appropriate period in which to consider the origins of this practice is the late 13 th century. It would also appear that the newly developed technology of architectural drafting was instrumental in this practice, and that the use of architectural drawings was of great significance for the spread of that design phenomenon that has become known as "micro-architecture." But whereas the forms pertaining to architectural drafting were firmly tied to the masons' lodge during the later Middle Ages, it was noc just masons that made use of such drawings; goldsmiths, as well as masons, appear to have played a significant role in the dissemination of "micro-architecture." 33 By focusing on process rather than the formal aspects of this phenomenon, 
however, what appears significant is that not only drafting techniques but the forms being drafted corresponded to the category of practical geometry, which directly linked design to the Liberal Arts. The process by which the Shrine of St. Gertrude was designed, as evidenced by its architecturalized form and its contract, can thus be seen to participate in a more purely intellectual apprehension of design than is implied in earlier practice.

The approach to design and to form that can be ascribed to the Shrine of St. Gertrude is, in fact, comparable in some respects with the contemporary theoretical writings of St. Thomas Aquinas on aesthetics and art, and a consideration of his ideas in relation to the shrine is enlightening. It is safe to say that Aquinas had no direct knowledge of architectural drawings; the many metaphors he uses involving a builder or architect specify a house as the actualization of a form or idea in the mind of the architect, "forma in mente artificus," without mentioning intermediaries. ${ }^{54}$ Yet, there is an analogy between the objective foundations with which Aquinas invests his conceptions of beauty and the formal structure of objects, and the approach to design evident in the Shrine of St. Gertrude. The executing goldsmiths of the shrine were called upon not only to address the transformation and manipulation of materials but in a significantly new way to realize as closely as possible a previously formulated design; similarly, Aquinas believed that "a thing has being insofar as it actualizes a rational structure that 'informs' the material." 55 Aquinas wrote that "a house ... is true if it turns out like the plan in the architect's mind," 56 and the rationale for the test piece mentioned in the shrine contract was very probably to ascertain, in a similar spirit, the formal integrity of the shrine, which is also evident in the architectural exactitude of so many of its elements. The clarity (claritas), integrity (integritas) and proportion (proportio) of the architectural elements in the shrine correspond to Aquinas' formal criteria of beauty, ${ }^{57}$ which he understood as "a purely intelligible reality, as moral harmony or metaphysical splendor." 58

The designer of the shrine did not dirty his hands by the mechanical working of materials. Rather, probably by means of drafting instruments, he manipulated geometrical shapes of a particular nature into an integrated design. He was working with the intelligible forms of practical geometry, by means of his operative intellect. ${ }^{59}$ He provided the scientia to which the executing goldsmiths applied their ars, ${ }^{60}$ and in fact, his position is entirely comparable to that of the architect, as it was emerging during this same period. ${ }^{61}$ That Jakemon d'Anchin was a designing goldsmith (as, later, were Brunelleschi and Schmuttermayer) rather than a designing mason is significant and points to a con- ception of design more independent of craft tradition than has previously been applied to this period. There was, nevertheless, a close connection between architectural design and design in general, which is fully evident in the architecturalized nature of the Shrine of St. Gertrude. It is possible that the architectural forms applied to the shrine were seen to have a specific symbolic value-along the lines, perhaps, of the Heavenly Jerusalem-but, lacking contemporary statements directly addressing this issue, it is difficult to identify such values with any degree of precision. It might also be said that such formal appropriation gives evidence for a process of stylistic reification, along the lines of what we now mean by "Rayonnant." ${ }^{"} 2$ More generally, these forms might be said to have constituted transcendentals, in their embodiment of geometrical principles which were firmly fixed in the process of design. ${ }^{63}$ The precisely drafted architectural drawings which appeared in the mid-13th century, and which were in all probability utilized in the design of the shrine, provided a specialized tool of a new kind which extended the mental process of conceptualization and design in a revolutionary way. ${ }^{64}$

In the Shrine of St. Gertrude we can apprehend a new approach to design which corresponds closely to the formalist conceptions of Aquinas. Taken together these are evidence of a newly emerging theoretical attitude towards art. Such an assertion, however, must certainly be considered in a historical context in which no single position held the field. As significant as these developments were for art and design, they did not entirely subsume other positions and attitudes of longer-standing artistic practice and criticism. Nevertheless, the rapid dissemination of "micro-architecture" and growing use of architectural drawings point to a substantial development in the process of Gothic design which affected craft training, workshop practice, the status of art objects and the position of the designer. A distinct difference can be noted between the critical appreciation of art which can be imputed to both the fabric of the shrine and the writings of Aquinas and that which characterizes earlier "Gothic" art. Despite Abbot Suger's use of the Ovidian topos that "the workmanship surpassed the material" in the marvellous works done for him, he enthuses primarily over workmanship as craft skill (ars) and over the splendor of materials rather than intelligible or metaphysical splendor. ${ }^{65} \mathrm{He}$ considered that material works of art could lead him anagogically towards the immaterial, but he does not appear to have seen them as participating directly in transcendental qualities. It is perhaps only by analogy that Aquinas' theoretical conceptions can be identified with the design conception of the Shrine of St. Gertrude, but the identity is a telling one, which invests the designer 
with intellectual rather than craft status. New approaches to design in the later 13 th century were providing artists with the means for a more directly intellectual approach to artistic creation, and there is much in the Shrine of St. Gertrude and its contract to inform us about that process.

* An earlier version of this study was read as a paper at the Canadian Conference of Medieval Art Historians held in Quebec City in 1993. I would like to thank Richard K. Morris for his very helpful comments and suggestions.

1 Ernst Günther Grimme, Goldschmiedekunst im Mittelalter: Form und Bedeutung des Reliquiars von 800 bis 1500 (Cologne, 1972), Ch. VI: "Abbild der Himmelsstadt - Schreine und Architekturreliquiare," 79-80, 125-51, and Marie-Madeleine Gauthier, "L'architecte," in her Routes de la Foi: reliques et reliquaires de Jérusalem à Compostelle (Paris, 1983), 149-54.

2 François Bucher, "Micro-Architecture as the 'Idea' of Gorhic Theory and Style," Gesta, XV (1976), 71-89.

3 See, for example, Erich Steingräber, "Beiträge zur gotischen Goldschmiedekunst Frankreichs," Pantheon, XX (1962), 15666. According to the Livre de la Taille of 1292, there were 116 goldsmiths and jewellers in Paris; see R.W. Lightbown, Secular Goldsmiths' Work in Medieval France: A History, Reports of the Research Committee of the Society of Antiquaries of London, no. XXXVI (London, 1978), 6. Probably the earliest known example of a shrine embodying "micro-architectural" details is the Grande Châsse of the Sainte-Chapelle, probably made in Paris between 1239/41 and 1248. The Shrine of St. Geneviève, made in Paris between 1238 and 1242, should also be considered in this context, although neither shrine survives; see Robert Branner, "The Grande Châsse of the Sainte-Chapelle," Gazette des Beaux-Arts, ser. 6, LXXVII (1971), 5-18, esp. 6, 10.

4 The Shrine of St. Gertrude has been considered recently by Claudine Donnay-Rocmans, "La châsse de Sainte Gertrude à Nivelles," Gazette des Beaux-Arts, ser. 6, LVIII (1961), 185-202, and Peter Cornelius Claussen, "Goldschmiede des Mittelalters: Quellen zur Struktur ihrer Werkstatt am Beispiel der Schreine von Sainte-Geneviève in Paris, Westminster Abbey in London, St Gertrud in Nivelles und St John in Beverley," Zeitschrift des deutschen Vereins für Kunstwissenschaft, XXXII/4 (Berlin, 1978), 46-86, esp. 73-78, 85-86, with further bibliography in both articles. Many aspects of the shrine remain to be studied sufficiently before a "monographic" understanding and appreciation of it is possible.

5 "Cartulaire du Chapitre noble de Nivelles," Brussels, Archives générales du royaume, MS A.G.R. (A.E.) no. 1417; for the contract, see Liber Grossus, fol. 493-94. Both Donnay-Rocmans, "La châsse de Sainte Gertrude," 201-02, and Claussen, "Goldschmiede des Mittelalters," 85-86, provide transcriptions of the contract, as does, inter alia, A. Asselin and C.-C. Dehaisnes, "Étude sur la châsse de Sainte Gertrude de Nivelles," Mémoires lus à la Sorbonne. Archéologie (1867), 245-57, esp. 255-57. There are minor differences between these transcriptions, and a de- finitive edition of the contract has yet to be published. That of Donnay-Rocmans appears generally reliable.

6 See Claussen, "Goldschmiede des Mittelalters," 86.

7 On the development and use of drafted architectural drawings in masons' workshops, see Wolfgang Schöllcr, "Le dessin d'architecture à l'époque gothique" in Roland Recht, ed., Les batisseurs des cathédrales gothiques, exhibition catalogue (Strasbourg, 1989), 227-35; Werner Müller, "Le dessin technique à l'époque gothique" in Recht, ed., Les batisseurs, 237-54.

8 The source of this date is J. Molanus, Natales Sanctorum Belgii (Louvain, 1595), 54; cited by Donnay-Rocmans, "La châsse de Sainte Gertrude," 199, n. 10, who raises the possibility that Molanus is mistaken and that the shrine was completed earlier, perhaps in 1293 when an examination of the relics of St. Gertrude is recorded.

9 Donnay-Rocmans, "La châsse de Sainte Gertrude," 193. For more on the patronage of Marie de Brabant, see Meredich Parsons Lillich, "Heraldry and Patronage in the Lost Windows of Saint-Nicaise de Reims," Actes du XXVIIe congrès international d'histoire de l'art (Strasbourg, 1-7 septembre 1989), 71-102. Marie de Brabant's involvement with the shrine must be carefully distinguished from that of her brother Jean I, duke of Brabant. There were great difficulties and conflicts between the chapter of St. Gertrude and the dukes of Brabant during the 13th century. In 1235, 1239 and 1253 the chapter of Nivelles reacted strongly to ducal incursions on its authority by "humiliating" the relics of St. Gertrude, which involved the placement of the former shrine on the ground in front of its altar. By analogy with similar practice at Chartres Cathedral, this could have been a sign of interdiction. See J.J. Hoebanx, L'abbaye de Nivelles des origines au XIVe siècle (Brussels, 1952), 231-49. Gobert de Perwez, grandson of Duke Godefroid III of Brabant, was the prévôt of the Nivelles chapter from 1240 to ca.1275; Hoebanx, L'abbaye de Nivelles, 333.

10 Donnay-Rocmans, "La châsse de Sainte Gertrude," 185.

11 The enamels have been associated with Parisian work in general and more specifically with the workshop of Guillaume Julien; see Donnay-Rocmans, "La châsse de Sainte Gertrude," 194-95. Before the shrine's recent destruction, the figures in the niches along its sides appear not to have been in their original order; see J. de Borghgrave d'Altena, "La Châsse de sainte Gertrude à Nivelles," Folklore brabanf̧on (1926), 71-118, esp. 73, and Donnay-Rocmans, "La châsse de Sainte Gertrude," 194. There is a brief record of a restoration of the shrine in 1848; see Asselin and Dehaisnes, "Etude sur la châsse," 253.

12 Margarete Fugmann, Frühgotische Reliquiare. Ein Beitrag zur rheinisch-belgischen Goldschmiedekunst des 13. Jahrhunderts (Leipzig, 1931), 82ff.

13 Donnay-Rocmans, "La châsse de Saince Gertrude," 201.

14 The goldsmiths of Paris were primarily located on the Grandpont. See Virginia Wylie Egbert, On the Bridges of Mediaeval Paris: A Record of Early Fourteenth-Century Life (Princeton, 1974), 28. 
15 Lightbown, Secular Goldsmiths' Work in Medieval France, 5. On the "force des trais" in general, see Hans R. Hahnloser, Villard de Honnecourt: Kritische Gesamtausgabe des Bauhüttenbuches ms. fr 19093 der Pariser Nationalbibliothek, 2nd edn (Graz, 1972), 1314; and Edgar de Bruyne, Études d'esthétique médiévale, III: Le XIIIe siècle (1946; Geneva, 1975), 251-61.

16 The manner in which such drawings were incorporated into workshop practice at this time may have been comparable to that mentioned in the treatise of Benvenuto Cellini, first published in 1568: "Those who did the best work in filigree were the men who had a good grip of drawing, especially designing from foliage $\&$ pierced spray work, for everything that you set to work upon requires first of all that you think it out as a design. And though many have practised the art without making drawings first ... still, those who made their drawings first did the best work." See C.R. Ashbee, trans., The Treatises of Benvenuto Cellini on Goldsmithing and Sculpture (1888; New York, 1967), 10.

17 Marion Campbell, "Gold, Silver and Precious Stones" in John Blair and Nigel Ramsay, eds., English Medieval Industries (London, 1991), 107-66, esp. 162.

18 Robert Branner, "Drawings from a Thirteenth-Century Architect's Shop: The Reims Palimpsest," Journal of the Society of Architectural Historians, XVII (1958), 9-21. See also Stephen Murray, "The Gothic Facade Drawings in the 'Reims Palimpsest'," Gesta, XVII (1978), 51-55.

19 The elevation of a chalice in the shape of a bird, dating from the 1360s, now in the Fürst Thurn und Taxis Kupferstichkabinett, Regensburg, appears to be the oldest surviving architectural drawing relating certainly to a piece of precious metalwork; see Die Parler und der schöne Stil 1350-1400: Europäische Kunst unter den Luxemburgern, exhibition catalogue (Cologne, 1978), I, 401-02; see also Walter Überwasser, "Spätgotische Baugeometrie. Untersuchungen an den Basler Goldschmiederissen," Jahresberichte der öffentliche Kunstsammlung Basel (1928-30), 79-122.

20 Recht, ed., Les batisseurs des cathédrales gothiques, 381-84.

21 Donnay-Rocmans, "La châsse de Sainte Gertrude," 193; Claussen "Goldschmiede des Mittelalters," 73.

22 Claussen, "Goldschmiede des Mittelalters," 76.

23 Claussen, "Goldschmiede des Mittelalters," 67.

24 "La Estoire de Seint Aedward le Rei," Cambridge University Library, MS Ee.3.59, fol. 65. This manuscript has recently been dated ca.1255-60, long before the shrine itself was finished; see N.J. Morgan, Early Gothic Manuscripts 1250-85, A Survey of Manuscripts Illuminated in the British Isles, IV, vol. 2 (London, 1987), no. 123. Just how closely the depiction of the shrine in the manuscript resembled the actual shrine is a problematic issue; see Claussen, "Goldschmiede des Mittelalters," 69.

25 The designer of the shrine, Jakemon d'Anchin, may have been intended to examine the test piece for the chapter, since he put his seal to the contract, as did the chapter and Nicolas de Douai (for both himself and Jaquemon de Nivelles, who presumably did not have his own seal). The contract of 1408 for the Shrine of St.
Germain, between the Abbey of Saint-Germain-des-Prés in Paris, on the one hand, and the goldsmiths Jean de Clichi, Gautier du Four and Guillaume Boey, on the other, specifies that the finished shrine should be examined by experts: "iceux ouvrages regardez \& visitez par orfeures \& gens souffisament \& en ce connoissans;" Virginia Wylie Egbert, "The Reliquary of Saint Germain," Burlington Magazine, CXIIA (Jan-June 1970), 359-65, esp. 36364. Needless to say, Jakemon d'Anchin, as designer, would have been eminently capable of evaluating how well the design for the Shrine of St. Gertrude had been executed in the test piece.

26 J. Lestocquoy, "Colard de Douai, orfevre d'Arras, et la châsse de Sainte-Gertrude à Nivelles," Bulletin de la Commission départementale des Monuments historiques du Pas-de-Calais, 2nd ser., VII/ 1 (1941), 68-77.

27 On the west facade of Reims Cathedral, see Jean Bony, French Gothic Architecture of the 12th and 13th Centuries (Berkeley, 1983), 401-03, 529 n.51, fig. 381; Bony comments on the "shrinelike spirit" of the facade. On the north transept facade of Notre-Dame, Paris, see Bony, French Gothic Architecture, 399, 528 n.47, fig. 377, and Robert Branner, St. Louis and the Court Style in Gothic Architecture (London, 1965), 76-80.

28 Donnay-Rocmans, "La châsse de Sainte Gertrude," 193, attributes the difference to the technical difficulties of transferring the feature to metalwork; it could more easily be argued, however, that glazed or openwork lower spandrels are far more technically difficult to achieve on a large scale in stone than on a small scale in metal.

29 On the south transept facade of Notre-Dame, see Bony, French Gothic Architecture, 400, and Branner, St. Louis and the Court Style, 101-02, fig. 112.

30 The tops of these buttresses appear to have undergone relatively recent modification. The plaster cast of the shrine in Nivelles shows them with tall lancets below the gables (fig. 2), while photographs show no lancets (fig. 1). I have been unable to ascertain the date of the plaster cast, however, which appears to be unreliable in many details; see Claussen, "Goldschmiede des Mittelalters," 73.

31 One other prominent example is the choir of Saint-Urbain, in Troyes, dating from the 1260 s and, like the Shrine of St. Gertrude, an example of the dissemination of ideas from the Ile-de-France; on Saint-Urbain, see Bony, French Gothic Architecture, 423-25, 534 n.19, fig. 403, and Branner, St. Louis and the Court Style, 106-08, pl. 117.

32 On the Lady Chapel of Saint-Germer-de-Fly, see Branner, St. Louis and the Court Style, 93-95, pl. 99, 104.

33 On the transepts of Saint-Denis, see Bony, French Gothic Architecture, 366-73, 377-80; Branner, St. Louis and the Court Style, 46-51.

34 A comparable use of a clairvoie can be seen on some of the folios of the slightly earlier St Louis Psalter (Paris, Bibl. Nat. MS Lat. 10525), which can be dated between 1253 and 1270. It is possible that both the Shrine of St. Gertrude and the St Louis Psalter refer to an earlier Parisian, and probably royal, shrine. 
35 "Double arches" of a rather different sort do occur in contemporary architectural practice, as for instance on inner doorways, such as that of the Lady Chapel of Saint-Germer-de-Fly and those on the slightly later transepts of Rouen Cathedral. These architectural examples, however, are not directly comparable with the shrine, as they display far more cohesion in their more lavish geometric display of tracery, which tends to fill completely the field between the two arches.

36 See, for instance, windows 117, 119, 126, and most particularly the right lights of window 118 and the left lights of window 116; these are illustrated in Yves Delaporte and Etienne Houvet, Les vitraux de la cathédrale de Chartres (Chartres, 1926), pl. CCXLVIII, CCXLIX (117); CCLI, CCLII (119); CXCV (126), CCV (118-R); CCXI (116-L). For examples in portal sculpture, see Willibald Sauerländer, Gothic Sculpture in France 1140-1270 (London, 1972), pls 88, 89 (Chartres Cathedral, north transept, right doorway, archivolts); 169 (Amiens Cathedral, west portal, left doorway, jamb canopies); and 178 (Villeneuve-l'Archevêque, west portal, left jamb canopies).

37 For instance, in the canopies of the bronze tomb of Pierre Mauclerc, the Duke of Brittany (d. 1250), formerly in SaintYved in Braine, and of the tomb of the bishops of Noyon, Baudouin III (d. 1175), Etienne de Nemours (d. 1221) and Renaud (d. 1188), formerly in the Abbey Church at Ourscamp, both now destroyed but recorded amongst the Gaignières drawings; see Jean Adhémar and Gertrude Dordor, "Les tombeaux de la collection Gaignières, dessins d'archéologie du XVIIe siècle," Gazette des Beaux Arts, LXXXIV (1974), 1-192, esp. no. 91, 230. Christopher Wilson, The Gothic Cathedral (London, 1990), 193, also signals the presence of ogees on the west portals of Auxerre Cathedral (ca.1260-80) and specifically relates them to a previous metalwork tradition, cf. the now destroyed bronze tomb of Queen Ingeborg of France (d. 1223), Adhémar and Dordor, "Les tombeaux," no. 166. Ogees also occur occasionally in late 13th-century French manuscript illumination; see, for example, the "La Somme le Roi" manuscript of ca. 1280 in London (B.L. Add. MS 28162), fol. 9v. I am not convinced of any English input into the design, although Bony compares the ogee on the shrine with English examples, seeing it as "an Arras work of the 1290s," and stating that "the facade end, with its ogeed gable, may well have been the last part to be finished;" Jean Bony, The English Decorated Style: Gothic Architecture Transformed 1250-1350 (Oxford, 1979), 22-7. It is unlikely that such a major element of the design would have been added at the last minute, and it is combined here, in any case, in a surprisingly out-of-date double arch form; neither are other elements of the shrine obviously English, although that has been claimed by Philippe Verdier, et al., L'art et la cour, exhibition catalogue (Ottawa, 1972), I, 119. Bony, however, provides a useful overview on the ogee arch.

38 One of the anonymous readers of this article suggested that the impending marriage of Marie de Brabant to the French king may have contributed in some way to the choice of Ile-de-France models. Whatever historical ties there may have been between the
Nivelles region and the Ile-de-France at this time, however, the rapid dissemination of Rayonnant architecture through much of western Europe makes the question of such specific ties difficult to evaluate. It is increasingly contentious, as well, simply to equate the style of architecture in the Ile-de-France with a French court style. It is beyond the scope of this essay to make judgements on such associations of style and political or social identity, an issue which deserves broader methodological re-evaluation, but see Caroline A. Bruzelius, "ad modum franciae: Charles of Anjou and Gothic Architecture in the Kingdom of Sicily," Journal of the Society of Architectural Historians, L (1991), 402-20. See also note 62.

39 Bony, French Gothic Architecture, 529 n.50; Robert Branner, "The Grande Châsse of the Sainte-Chapelle," 7-8; Gauthier, Les routes de la foi, 162-64.

40 On the Shrine of St. Taurin, see Bony, French Gothic Architecture, 401,529 n.50 (with bibliography), pl. 380. On the Floreffe Triptych, see Grimme, Goldschmiedekunst im Mittelalter, 49-50, fig. 22; Gauthier, Les routes de la foi, 149-51; and Verdier, L'art et la cour, no. 39.

41 On the architecturalization of canopies in stained glass, see James Bugslag, "Antique Models, Architectural Drafting and Pictorial Space: Canopies in Northern French Stained Glass 1200-1350," Ph.D. diss., University of East Anglia, 1991.

42 See, for example, C. Evcleigh Woodruff, "The Financial Aspects of the Cult of St. Thomas of Canterbury," Archaeologia Cantiana, LXIV (1932), 13-33.

43 See, for example, Peter Pause, Gotische Architekturzeichnungen in Deutschland, Ph.D. diss., Rheinische Friedrich-WilhelmsUniversität, 1971 (Bonn, 1973); Christoph Gerlach, Vorzeichnungen auf gotischen Planrissen, Ph.D. diss., Universität Hannover, 1984, Dissertationen zur Kunstgeschichte 23 (Cologne, 1986); Werner Müller, Grundlagen gotischer Bautechnik (Munich, 1990).

44 Lon R. Shelby, Gothic Design Techniques: The Fifteenth-Century Design Booklets of Mathes Roriczer and Hanns Schmuttermayer (Carbondale, Ill., 1977). It is difficult to discover generative aspects of proportional and geometric design under the most ideal of circumstances, but the almost complete destruction of the Shrine of St. Gertrude makes such an analysis next to impossible, despite the survival of the plaster cast of the shrine in Nivelles. Nevertheless, it is worth mentioning that the dimensions given for the shrine by Asselin and Dehaisnes, "Ecude sur la châsse," 245-46, in 1867, and repeated unquestioningly in the later literature, are: length $1.8 \mathrm{~m}$, width $0.54 \mathrm{~m}$, and height $0.80 \mathrm{~m}$. These dimensions yield exact proportional relations: the ratio of length to height is $9: 4$ and that of length to width is $10: 3$.

45 Franklin Toker, "Gothic Architccture by Remotc Control: An Illustrated Building Contract of 1340," Art Bulletin, LXVII (1985), 67-95.

46 Adolphe Hocquet, Le rayonnement de l'art tournaisien aux XIIIe et XIVe siècles. Nouvelles preuves (Tournai, n.d. [1924]), 25-26. 
Jacques Couvés is engaged to make a tomb slab to the memory of Canon Jean de Mur, archdeacon of Ghent: "et entre le bordure et l'ymagine dou diakene doit avoir I pilier à cescun lés dou diakene estofet de pourtrait de vraie machonnerie enbasset et encapitelet de sous basses et de cimaises ausi souffisantment com il appert en I parkemin que li testamenteur en ont; et par diseure ces II piliers doit avoir I boin tabernacle ausi souffisant en toutes manières com est li tabernacles ou parkemin ke li testamenteur en ont." Archives de l'état, greffe scabinale de Tournai, original on parchment.

47 See F.A. Grecnhill, Incised Effigial Slabs, 2 vols (London, 1976), in passim.

48 Egbert, "The Reliquary of Saint Germain," with illustrations and a transcription of the contract.

49 Paul Binski, The Painted Chamber at Westminster, Society of Antiquaries Occasional Papers (New Series), IX (London, 1986), 74. The separation of execution and design in England is also briefly treated by Nigel Ramsay, "Arrists, Craftsmen and Design in England, 1200-1400" in Age of Chivalry: Art in Plantagenet England 1200-1400, J. Alexander and P. Binski, eds., exhibition catalogue (London, 1987), 49-54, in which it is mentioned that "in 1331 Queen Philippa is found paying the London goldsmith Simon de Berking $2 s$ for the drawing of a ship in parchment, to have a model by which a ship for alms (or nef) could be made."

50 Kathleen Morand, Jean Pucelle (Oxford, 1962), 2, 31.

51 Earlier possibilities for the separation of design and execution occur in the realm of architecture, but they are not well enough documented to specify the respective roles of "architect" and executing master mason(s). For instance, the "design" of Cluny III by the monk Gunzo could have consisted of no more than a set of proportional "specifications" and the major elements of the ground plan; see K.J. Conant, Cluny: Les églises et la maison $d u$ chefd'ordre, Mediaeval Academy of America Publication No. 77 (Mâcon, 1968), 75-80.

52 Implicit in Cellini's treatise on goldsmithing is his separation of design from the "craft" of goldsmithing; see Ashbee, trans., The Treatises of Benvenuto Cellini, in passim.

53 This connection, I believe, can be seen in the Azon le Tort window in Rouen Cathedral, which has convincingly been connected with a chaplaincy founded in 1266 and which clearly took as its model the so-called Shrine of St. Romain, which had only recently arrived in the Cathedral, probably from Paris. Not only the figure of the Virgin and Child in the stained glass, but also the architectural framing elements, with their distinctive, leafy crockets, appear to have been copied dircctly from the shrinc. For the Azon le Tort window, see Louis Grodecki and Catherine Brisac, Gothic Stained Glass 1200-1300 (London, 1985), 160-61, 257; for the Shrine of St. Romain, see Recht, ed., Les batisseurs des cathédrales gothique, 444-45.

54 Umberto Eco, The Aesthetics of Thomas Aquinas, trans. Hugh Bredin (Cambridge, Mass., 1988), 101, 204; and de Bruyne, Études d'esthétique médiévale, 326-31.
55 Eco, The Aesthetics of Thomas Aquinas, 66.

56 ST, I, 16, 1c; cited in Eco, The Aesthetics of Thomas Aquinas, 101.

57 Eco, The Aesthetics of Thomas Aquinas, $64 \mathrm{ff}$.

58 Eco, The Aesthetics of Thomas Aquinas, 6.

59 Eco, The Aesthetics of Thomas Aquinas, 167

60 Jean Mignot's statements that "the theory (scientia) of geometry $\ldots$ is one thing and the practice (ars) another" and that "ars sine scientia nihil est" were made much later than the period in question, but the idea can be traced as far back as Plato, who stated that architects "contribute knowledge, not craftsmanship." For Jean Mignot, see Paul Frankl, The Gothic: Literary Sources and Interpretations through Eight Centuries (Princeton, 1960), 76-77; Plato's statement is cited in Spiro Kostof, "The Practice of Architecture in the Ancient World: Egypt and Greece," idem, ed., The Architect (New York and Oxford, 1977), 3.

61 See, for instance, Spiro Kostof, "The Architect in the Middle Ages, East and West," idem, ed., The Architect, 59-95.

62 Burchard von Hall's characterization (ca.1280) of the newly constructed church of Wimpfen-im-Tal by a Parisian architect as "opus francigenum" is an appropriate contemporary characterization of Rayonnant style to compare with the Shrine of St. Gertrude. It implies that this style stood out noticeably in its immediate geographical context but tells us little about symbolic values. See Frankl, The Gothic, 55-57. Charles of Anjou's use of the term "ad modum franciae" for tiles for his new monastery of S. Maria di Realvalle in Sicily (1279) potentially has more specifically ideological connotations; see Bruzelius, "ad modum franciae." These characterizations are mirrored in a later source, specifically in relation to metalwork; in 1405, the Duke of Burgundy purchased several silver vessels "de la fachon de Paris;" see Lestocquoy, "Colard de Douai," 76.

63 On Aquinas' characterization of geometric constructions as intelligible forms, see Vincent Edward Smith, St. Thomas on the Object of Geometry (Milwaukee, 1954). It might also be useful to consider the form of the shrine with respect to Aquinas' concept of "parabolic" sense, which is "the meaning of a verbal or pictorial image which is so appropriate and so well proportioned to its sense that it proclaims itself to be at one with it;" see Eco, The Aesthetics of Thomas Aquinas, 153-59.

64 For a recent repositioning of the intellectual basis of Gothic architecture from Panofskian "mental habits" to the more concrete "mental process," see Charles M. Radding and William W. Clark, Medieval Architecture, Medieval Learning: Builders and Masters in the Age of Romanesque and Gothic (New Haven and London, 1992).

65 "Materiam superabat opus;" Erwin Panofsky, ed. and trans., Abbot Suger on the Abbey Church of St.-Denis and its Art Treasures 2nd edn (Princeton, 1979), 62-63. Suger's active role as an architectural designer has recently been played down significantly by Peter Kidson, "Panofsky, Suger and St. Denis," Journal of the Warburg and Courtauld Institutes, L (1987), 1-17. 